\title{
Risk Assessment of Heavy Metals via Consumption of Contaminated Vegetables Collected from Different Agricultural Fields and Market Sites
}

\author{
Arbind Kumar ${ }^{1, *}$, Seema ${ }^{2}$, Vipin Kumar ${ }^{3}$ \\ ${ }^{1}$ Department of Chemistry, Darshan Sah College, Bhupendra Narayan Mandal University, Madhepura, India \\ ${ }^{2}$ Department of Botany and Plant Physiology, College of Horticulture, Bihar Agricultural University, Sabour, India \\ ${ }^{3}$ Department of Chemistry and Environmental Science, Katihar Engineering College, Aryabhatt Knowledge University, Patna, India
}

\section{Email address:}

drarbindktr@gmail.com (A. Kumar)

${ }^{*}$ Corresponding author

\section{To cite this article:}

Arbind Kumar, Seema, Vipin Kumar. Risk Assessment of Heavy Metals via Consumption of Contaminated Vegetables Collected from Different Agricultural Fields and Market Sites. Advances in Biochemistry. Vol. 5, No. 3, 2017, pp. 47-56. doi: 10.11648/j.ab.20170503.13

Received: May 12, 2017; Accepted: May 23, 2017; Published: July 4, 2017

\begin{abstract}
The present study was conducted with an aim to compare heavy metals $(\mathrm{Cu}, \mathrm{Zn}, \mathrm{Cd}$ and $\mathrm{Pb})$ accumulation potential of some of the commonly grown vegetables like brinjal, cauliflower, spinach and coriander collected from different agricultural (production) and market sites of Katihar city. The accumulation of $\mathrm{Cd}, \mathrm{Pb}, \mathrm{Cu}$ and $\mathrm{Zn}$ in test vegetables was higher in market sites then those at all agricultural lands and elevated by 47.84, 64.84, 21.3, and 9.91\% in brinjal, 36.19, 78.09, 21.83, and $6.50 \%$ in cauliflower, $34.52,49.50,9.1$, and $9.97 \%$ in spinach and $27.86,47.05,10.34$, and $6.13 \%$ in coriander, respectively and was observed maximum in brinjal (143.89\%) followed by cauliflower (142.61\%), spinach (103.09\%), and coriander (91.38\%). The population load index (PLI), transfer factor (TF), daily intake of metals (DIM) and health risk index (HRI) were also studied. The maximum value of PLI was found for $\mathrm{Zn}(35.06 \%)$ and minimum for $\mathrm{Pb}(0.178 \%)$ in soil collected from production sites. The TF of heavy metals in vegetable collected from market sites was found to be higher than vegetable collected from production sites and could be one of the possible reasons for health risk in human via their consumption. The average daily intake of $\mathrm{Cd}, \mathrm{Pb}, \mathrm{Cu}$ and $\mathrm{Zn}$, by adults in vegetables collected from market sites were 5.38, $1.20,4.606$ and $0.336 \%$ of provisional tolerable daily intake. The HRI value of all individual vegetables was below 1.0. Therefore, it is suggested that regular monitoring of heavy metals in vegetables is essential to prevent excessive build-up of heavy metals in the food chain and appropriate precautions should also be taken at the time of transportation and marketing of vegetables.
\end{abstract}

Keywords: Soil, Vegetables, Heavy Metals, Population Load Index, Transfer Factor, Daily Intake, Health Risk Index

\section{Introduction}

Vegetables are important part of human diet throughout the world, as they are rich sources of essential important nutrients, such as carbohydrates, proteins, vitamins, minerals, trace elements as well as antioxidants and metabolites, [1, 2]. They also play an important role to control various chronic diseases by acting as buffering media for acid substances formed during digestion of food [2]. The accumulation of heavy metals in plant vary with factors such as climate, soil properties, atmospheric deposition, plant species, and soil to plant factors of metals [3, 4]. These toxic metals not only inhibit root growth but can also hamper physiological processes including uptake of nutrients. The absorption of heavy metals from the soil depends on different factors such as $\mathrm{pH}$, organic matter, soil metal availability, cation exchange capacity, plant species, plant growth stages and presence of other metals present in soil [4]. The major sources of metals are wastewater untreated or partially treated industrial effluents, municipal wastes and vehicles [5, 6]. Aerosols also contribute to high levels of toxic metals on the surface of vegetables during the production, transportation, and marketing that depend upon various 
factors such as level of the pollutants, especially dust in air, nature of road, traffic loads and period of exposure or duration to which the vegetables are exported for marketing[7]. During harvesting, transportation and marketing of vegetables, emissions of heavy metals from industries and vehicles may be deposited on the surface of vegetables [8]. Atmospheric deposition can significantly elevate the levels of heavy metals in vegetables sold in the market were also reported by Sharma et al. $(2008 \mathrm{a}, \mathrm{b})$ [9, $10]$.

Some metals such as $\mathrm{Mn}, \mathrm{Cu}, \mathrm{Zn}, \mathrm{Co}, \mathrm{Mo}$ and Fe are essential for human life in appropriate concentration as they catalyse enzymatic activities in human body, but in excess they become poisonous [11]. They get magnified with rising tropic level and ultimately get accumulated in human beings where they cause chronic and acute ailments and even death [12]. Some of these heavy metals form complexes with carboxylic $(-\mathrm{COOH})$, amino $\left(-\mathrm{NH}_{2}\right)$, imino $(>\mathrm{NH})$ and thiol $(-\mathrm{SH})$ groups present in the proteins and they disturb the activity of the proteins to catalyse the function of enzymes [13]. The new biological complex molecules thus formed lose their function which result in break down or cell damage $[13,14]$. Three heavy metals of greatest health concern are $\mathrm{Cd}, \mathrm{Pb}$ and $\mathrm{Hg}$. There is no biological need of any of them. The increase in environmental pollution caused by toxic metals is of great concern because of their carcinogenic properties, their non-biodegradability and bio-accumulation [15]. Continuous human consumption of contaminated vegetables may cause accumulation of heavy metals in the kidney and liver and can cause disturbance of biochemical process and cause cardiovascular, kidney, liver, nervous and bone diseases [16-18].
The assessment of heavy metal concentration in the vegetables from the market sites are being carried on in some developed countries and there are very few published data in India, however not available in the literature of Katihar city. Thus the aim of the research work was to monitor and assess the concentration of heavy metals $(\mathrm{Cu}, \mathrm{Zn}, \mathrm{Cd}$ and $\mathrm{Pb})$ in some selected vegetables collected from different agricultural (production) fields and market sites of Katihar city, Bihar, India and also to estimate health hazard through their consumption.

\section{Materials and Methods}

\subsection{Site Description}

Katihar is an agricultural district that covers 3056 square $\mathrm{km}$ areas and located at $25.53^{\circ} \mathrm{N}$ and $87.58^{\circ} \mathrm{E}$. Kathiar is too small but has large number of small scale industries. The wastewater and disposal of sewage water are drained to the agricultural land where these are used for growing crops and vegetables. Two study sites were selected i.e., market site (in between $0-5 \mathrm{~km}$ ) and agricultural land (in between $5-15 \mathrm{~km}$ from the city centre). Freshly samples of some commonly grown vegetables i.e., brinjal (Solanum melongena), cauliflower (Brassica oleracea L.), spinach (Spinacia oleracea L.) and coriander (Coriandrum sativum) were collected simultaneously from the market sites and agricultural fields around Katihar city, Bihar, India during October 2014 to March 2015 (Table 1). The name and number of market sites and agricultural fields are listed in Table 2 .

Table 1. Green vegetable samples collected from agricultural fields and market sites.

\begin{tabular}{llllll}
\hline S. $\mathbf{N}$ & Common name & Vernacular name & Botanical name & Part used & Family \\
\hline 1 & Brinjal & Baigan & Solanum melongena & Whole fruit & Solanaceae \\
2 & Cauliflower & Phool Gobi & Brassica oleracea $\mathrm{L}$ & Fruity flowers & Brassicaceae \\
3 & Spinach & Palak & Spinacia oleraceae L & Leaves & Amaranthaceae \\
4 & Coriande & Dhania & Coriandrum sativum & Leaves & Apiaceae \\
\hline
\end{tabular}

Table 2. Name and no. of market sites and agricultural (production) fields in the study area.

\begin{tabular}{|c|c|c|c|c|c|c|c|c|c|}
\hline \multirow{2}{*}{\multicolumn{2}{|c|}{$\begin{array}{l}\text { Market sites } \\
\text { All Test Vegetable }\end{array}$}} & \multicolumn{8}{|c|}{ Agricultural (production) fields } \\
\hline & & Brinjal & & Cauliflowe & & Spinach & & Coriander & \\
\hline Site name & No. & Site name & No. & Site name & No. & Site name & No. & Site name & No. \\
\hline New Marker & I & Belwa & 1 & Varmali & 8 & Sarinda & 15 & Boodnagar & 20 \\
\hline Bhagwan Chock & II & Govind Chock & 2 & Bastol & 9 & Sarbasa & 16 & Daheria & 21 \\
\hline Chalisa Hatia & III & Hajipur & 3 & Ranipatra & 10 & Sonoli & 17 & Kuretha & 22 \\
\hline Mirchaibari & IV & Sarifganj & 4 & Dalan & 11 & Haplaganj & 18 & Sernia & 23 \\
\hline Mahamood Chock & $\mathrm{V}$ & Hawaiadda & 5 & Rampur & 12 & Chattabari & 19 & Pharthali & 24 \\
\hline ----------------------- & --- & Sirsa & 6 & Pranpur & 13 & ------------ & ---- & 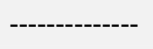 & --- \\
\hline 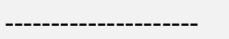 & ---- & Mania & 7 & Rhotra & 14 & ------------ & ---- & 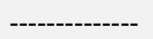 & ---- \\
\hline
\end{tabular}

On the basis of the production capacity of these vegetables and transportation to the market, 24 sites were selected in the agricultural fields and five locations in the market (Figure 1). Among these agricultural fields 11 sites $(3,4,5,7,10,11,12$, 
$14,21,22$ and 24) are located vicinity to the national highway (NH) and 7 sites $(6,13,16,17,18,19$ and 23) are located close to brick kilns industries. Three locations (III, IV and $\mathrm{V}$ ) in market are located in the dense populated area and heavy traffic on a narrow road and three (I, III and V) are also close to industrial, commercial and residential areas.

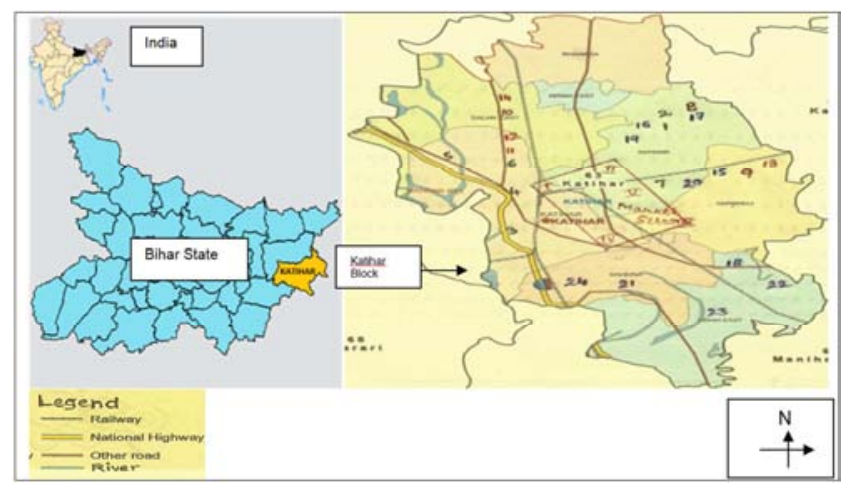

Figure 1. Study area and location of sampling points.

\subsection{Soil Sampling}

Soil samples were collected from 24 agricultural fields by digging a monolith of $10 \mathrm{~cm} \times 10 \mathrm{~cm} \times 10 \mathrm{~cm}$ size by using plastic scooper. Each field was first subdivided into five parts, then all collected soil samples were mixed together to form composite soil sample from each field. Non-soil particles were removed from each sample, dried at $40^{\circ} \mathrm{C}$ for $48 \mathrm{~h}$ and ground into fine powder and then sieved through 2 mm nylon sieve. After this each sample was transferred into air tight polyethylene bag and brought into laboratory for analysis as described by Lei et al. (2008) [19].

\subsection{Vegetable Sampling}

The vegetables selected for heavy metal analysis were brinjal, cauliflower, spinach and coriander. Brinjal and cauliflower were collected from 7, 7 sites; spinach and coriander were collected from 5, 5 sites from agricultural fields respectively during the growing season and simultaneously from five (I, II, III, IV and V) market sites. All the collected vegetables (one intact inflorescence head of cauliflower and $1 \mathrm{~kg}$ each of brinjal, spinach and coriander) were washed with tap water to remove the soil particles and then uneatable parts were removed. The edible part was sliced into pieces and dried separately on sheet of filter paper, then dried in oven at $75^{\circ} \mathrm{C}$ for $24 \mathrm{~h}$ and then crushed and sieved at room temperature and digested by using the method described by Jamail et al. (2009) [20].

\subsection{Digestion of Samples}

$1 \mathrm{gm}$ of each sample of soil and vegetable was placed in $100 \mathrm{~mL}$ beaker separately and digested with $15 \mathrm{~mL}$ of triacid mixture i.e. $\mathrm{HNO}_{3}, \mathrm{HClO}_{4}$ and $\mathrm{H}_{2} \mathrm{SO}_{4}$ at 5:1:1 ratio at $80^{\circ} \mathrm{C}$ on an oven plate till the solution becomes transparent [21]. The solution thus obtained was filtered and each filtrate was made to $50 \mathrm{~mL}$ by mixing deionised water and subjected to atomic absorption spectrophotometer for analysis for heavy metal $(\mathrm{Pb}, \mathrm{Cd}, \mathrm{Cu}$ and $\mathrm{Zn})$.

\section{Data Analysis}

\subsection{Pollution Load Index (PLI)}

The degree of soil pollution for each metal was computed as pollution load index by using following modified equation, (Liu et al., 2005) [22].

$$
\mathrm{PLI}=\mathrm{C}_{\text {Soil }} / \mathrm{C}_{\text {Reference }}
$$

Where, $\mathrm{C}_{\text {Soil }}$ and $\mathrm{C}_{\text {Reference }}$ represent the metal concentration in the wastewater irrigated and reference soil respectively.

\subsection{Transfer Factor (TF)}

The metal transfer factor from soil to plant was determined by using following formula, (Cui et al., 2005) [23].

$$
\mathrm{TF}=\mathrm{C}_{\text {Plant }} / \mathrm{C}_{\text {Soil }}
$$

Where, $\mathrm{C}_{\text {plant }}$ and $\mathrm{C}_{\text {soil }}$ represent the metal concentration in plant fresh weigh and in soil dry weigh respectively.

\subsection{Daily Intake of Metals (DIM)}

The daily intake of heavy metal was calculated by using following formula, (Chary et al., 2008) [24].

$$
\mathrm{DIM}=\mathrm{C}_{\text {metal }} \times \mathrm{D}_{\text {food intake }} \times \mathrm{C}_{\text {factor }} / \mathrm{B}_{\text {average body weight }}
$$

Where $\mathrm{C}_{\text {metal }}, \mathrm{D}$ food intake, $\mathrm{B}$ average weight and $\mathrm{C}_{\text {factor }}$ represent heavy metal concentration in plant $\left(\mathrm{mg} \mathrm{kg}^{-1}\right)$, daily intake of vegetable $\left(\mathrm{gm} \mathrm{day}^{-1}\right.$ person $\left.{ }^{-1}\right)$, average body weight $(\mathrm{kg})$ and conversion factor $(0.085)$ respectively. The conversion factor was used to convert fresh green vegetables weight to dry weight, as described by Rattan et al. (2005) [25]. The average body weight was considered to be $55 \mathrm{~kg}$ by conducting survey of 100 adult (male and female) people from study areas in each was determined by formal interview conducted with people of study areas during period of sampling. The average daily vegetable in take for adult was considered to be $250 \mathrm{gm} \mathrm{day}^{-1}$ person ${ }^{-1}$ which was determined by formal interview conducted with people of study areas.

\subsection{Health Risk Index (HRI)}

The value of HRI depends upon the daily intake of metals (DIM) and reference oral dose $\left(\mathrm{Rf}_{\mathrm{D}}\right)$, which was computed as described by Jan et al. (2010) [26]. The HRI less than 1 means exposed population said to be safe (US-EPA IRIS, 2006) [27]. $\mathrm{Rf}_{\mathrm{D}}$ value for $\mathrm{Cu}, \mathrm{Pb}, \mathrm{Cd}$, and $\mathrm{Zn}$ is $0.04,0.004$, 0.001 and $0.30(\mathrm{mg} / \mathrm{kg} \mathrm{bw} /$ day) respectively [27].

$$
\mathrm{HRI}=\mathrm{DIM} / \mathrm{Rf}_{\mathrm{D}}
$$

\subsection{Statistical Analysis}

All statistical analysis were performed on lenovo тм computer 
using the Microsoft EXCEL and Word 2007 format. Similarly, the significance of differences between the concentrations of heavy metals in soil and vegetables were calculated by using Casio calculator (made in China) $f x-991$ MS. A probability of $\mathrm{p}>0.05$ was considered statically significant.

\section{Results and Discussion}

\subsection{Accumulation of Heavy Metals in Soil Samples}

Results revealed that concentration of heavy metals $(\mu \mathrm{g} / \mathrm{g})$ in test soil collected from different vegetable production fields ranged from $0.40-2.35$ for $\mathrm{Cd}, 0.10-1.57$ for $\mathrm{Pb}, 10.2$ - 24.3 for $\mathrm{Cu}$ and 80.2 -123.3 for $\mathrm{Zn}$ (Table 3). The upper limits of $\mathrm{Cd}, \mathrm{Cu}$ and $\mathrm{Zn}$ in the test soil were higher than uncontaminated soil $(\mathrm{Cd} ; 1.0, \mathrm{Cu} ; 15$ and $\mathrm{Zn} ; 100 \mu \mathrm{g} / \mathrm{g})$ and lower for $\mathrm{Pb}(50.0 \mu \mathrm{g} / \mathrm{g})$ as reported by Temmerman et al. (1984) [28]. But the upper limits of heavy metals were below the upper permissible limits as recommended by Prevention of food Adulteration (PFA) standards (6, 500, 270 and 300 $\mu \mathrm{g} / \mathrm{g}$, respectively for $\mathrm{Cd}, \mathrm{Pb}, \mathrm{Cu}$ and $\mathrm{Zn}$ ) as guided by Awasthi (2000) [29]. Results also revealed that about 11 vegetable production sites, which were near to national highway and about 7 sites which were in the vicinity of brick kilns showed higher concentration of $\mathrm{Cd}, \mathrm{Pb}, \mathrm{Cu}$ and $\mathrm{Zn}$ than those agricultural fields which were free from special emission (Figure 2).

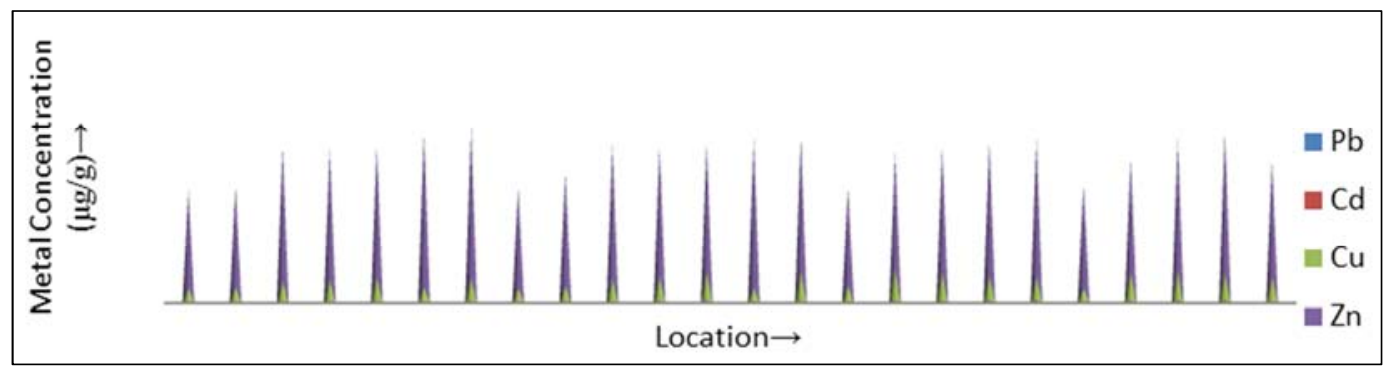

Figure 2. Metal concentration in soil at 24 sites of Agricultural fields at study area.

On the survey of study areas it was found that continuous irrigation of agricultural land with sewage and wastewater, use of $\mathrm{Zn}$ containing pesticides, $\mathrm{Zn}$ containing fertilizers and ash from brick kilns may be possible reasons of $\mathrm{Zn}$ accumulation in the soil $[30,31]$. The percentage pollution load index (PLI) of each metal in soil at SWI zone compared with PFA standard (Awasthi, 2000) value was in the order of $\mathrm{Cd}$ (20\%), $\mathrm{Cu}$ (6.18\%), $\mathrm{Pb}(0.18 \%)$ and $\mathrm{Zn} \mathrm{(35.063 \% ),}$ (Table 3).

Table 3. Accumulation of heavy metals $(\mu \mathrm{g} / \mathrm{g})$ in the soil from agricultural fields $(n=24)$.

\begin{tabular}{lllll}
\hline Statistical data & Pb & $\mathbf{C d}$ & $\mathbf{C u}$ & $\mathbf{Z n}$ \\
\hline Minimum & 0.10 & 0.40 & 10.2 & 80.20 \\
Maximum & 1.57 & 2.35 & 24.3 & 123.3 \\
Mean & 0.89 & 1.20 & 16.70 & 105.18 \\
Median & 1.42 & 1.07 & 16.30 & 113.8 \\
Sum of total value & 26.13 & 28.89 & 400.9 & 25.244 \\
Simple Standard Deviation & 0.494 & 0.561 & 4.648 & 13.815 \\
Prevention of food Adulteration & 500 & 6.00 & 270 & 300 \\
Pollution Load Index & 0.00178 & 0.20 & 0.06185 & 0.3506 \\
\hline
\end{tabular}

\subsection{Accumulation of Heavy Metals in Vegetable Samples}

Results revealed that accumulation of heavy metals was found to be high in all vegetables collected from market sites compared to agricultural fields (Table 4). The maximum concentration of heavy metals $(\mu \mathrm{g} / \mathrm{g})$ were recorded at sites -
7 (1.25), 12 (1.35), $16(3.1)$ and 24 (2.95) for $\mathrm{Cd}$, at sites7(1.34), 14 (1.32), 17(1.47) and 22 (1.95) for $\mathrm{Pb}$, at sites-5 (25.3), 12 (26.2), $16(27.4)$ and 21 (24.5) for $\mathrm{Cu}$, at sites$7(130.3), 12$ (142.7), 18(134.3) and 24 (134.6) for $\mathrm{Zn}$ in brinjal, cauliflower, spinach and coriander respectively, collected from agricultural fields as shown in Figures 3-18. The high accumulation of heavy metals in the test vegetables collected from agriculture fields at 5, 7, 12, 14, 21.22 and 24 may be due to their location near to national highway and sites 16,17 and 18 may be due to being very close to brick kiln industries. The high concentration of heavy metals in the tested vegetables at sites 7, 12, 16 and 24 may also be ascribed due to their locations in the vicinity of brick kiln industries and also very close to national highway.

The concentration of $\mathrm{Zn}$ ranged from 95.2-140.1, 97.8143.7, 99.5-147.3 and 95.3-141.4 $\mu \mathrm{g} / \mathrm{g}$ in brinjal, cauliflower, spinach and coriander respectively collected from market sites (Table 4). In all vegetables collected from agricultural fields and market sites the accumulation of $\mathrm{Zn}$ was high followed by $\mathrm{Cu}, \mathrm{Cd}$ and $\mathrm{Pb}$ than permissible limits of PFA standard $(50 \mu \mathrm{g} / \mathrm{g})$. The maximum concentration of $\mathrm{Cu}$ in vegetables collected from market at site- $\mathrm{V}$ in cauliflower $(37.7 \mu \mathrm{g} / \mathrm{g})$ and in brinjal $(35.4 \mu \mathrm{g} / \mathrm{g})$, which were higher than permissible limit guided by PFA $(30 \mu \mathrm{g} / \mathrm{g})$, whereas minimum concentration of $\mathrm{Cu}$ was found to be $16.4(\mu \mathrm{g} / \mathrm{g})$ in brinjal at market site-I as shown in Figures 11-12.

Table 4. Accumulation of heavy metals $(\mu \mathrm{g} / \mathrm{g})$ in the vegetables collected from production and market sites.

\begin{tabular}{|c|c|c|c|c|c|c|c|c|}
\hline \multicolumn{5}{|c|}{ Agricultural (production) Fields } & \multicolumn{4}{|c|}{ Market Sites } \\
\hline Metals & Brinjal & Cauliflower & Spinach & Coriander & Brinjal & Cauliflower & Spinach & Coriander \\
\hline \multicolumn{9}{|c|}{ Cadmium } \\
\hline Min. & 0.45 & 0.45 & 0.86 & 0.82 & 0.58 & 0.68 & 0.98 & 0.98 \\
\hline
\end{tabular}




\begin{tabular}{|c|c|c|c|c|c|c|c|c|}
\hline \multicolumn{5}{|c|}{ Agricultural (production) Fields } & \multicolumn{4}{|c|}{ Market Sites } \\
\hline Metals & Brinjal & Cauliflower & Spinach & Coriander & Brinjal & Cauliflower & Spinach & Coriander \\
\hline Max. & 1.25 & 1.35 & 3.10 & 2.95 & 1.21 & 2.20 & 3.48 & 3.81 \\
\hline Median & 0.95 & 1.01 & 2.21 & 2.12 & 1.21 & 1.24 & 2.71 & 2.71 \\
\hline Mean & 0.786 & 0.909 & 1.802 & 1.888 & 1.162 & 1.238 & 2.424 & 2.414 \\
\hline$\sigma_{\mathrm{n}-1}$ & 0.348 & 0.390 & 0.922 & 0.985 & 0.586 & 0.599 & 1.311 & 1.307 \\
\hline$\Sigma_{\mathrm{n}}$ & 5.50 & 6.36 & 9.01 & 9.440 & 5.81 & 6.19 & 12.12 & 12.07 \\
\hline$\%$ Elevation & ------ & ------ & ------ & ----- & 47.84 & 36.19 & 34.52 & 27.86 \\
\hline \multicolumn{9}{|l|}{ Lead } \\
\hline Min. & 0.20 . & 0.25 & 0.85 & 0.80 & 0.25 & 0.35 & 1.15 & 1.01 \\
\hline Max. & 1.34 & 1.32 & 1.47 & 1.95 & 2.54 & 2.84 & 1.75 & 2.43 \\
\hline Median & 1.25 & 1.25 & 1.47 & 1.95 & 2.03 & 1.85 & 1.75 & 1.66 \\
\hline Mean & 1.041 & 1.05 & 1.01 & 1.05 & 1.716 & 1.87 & 1.51 & 1.544 \\
\hline$\sigma_{n-1}$ & 0.412 & 0.377 & 0.257 & 0.474 & 0.868 & 0.934 & 0.236 & 0.558 \\
\hline$\Sigma_{\mathrm{n}}$ & 7.29 & 7.35 & 6.48 & 7.780 & 8.58 & 9.35 & 7.55 & 7.72 \\
\hline$\%$ Elevation & ----- & ------- & ------ & ------ & 64.84 & 78.09 & 49.50 & 47.05 \\
\hline \multicolumn{9}{|l|}{ Copper } \\
\hline Min. & 15.3 & 15.8 & 17.5 & 14.8 & 16.4 & 16.7 & 19.7 & 17.3 \\
\hline Max. & 25.3 & 26.2 & 27.4 & 24.5 & 35.4 & 37.7 & 28.5 & 26.3 \\
\hline Median & 22.4 & 25.8 & 25.3 & 22.8 & 27.4 & 28.2 & 27.7 & 24.7 \\
\hline Mean & 19.8 & 20.93 & 22.68 & 20.12 & 24.02 & 25.5 & 24.74 & 22.2 \\
\hline$\sigma_{\mathrm{n}-1}$ & 3.612 & 4.121 & 4.047 & 3.885 & 7.658 & 8.09 & 3.66 & 3.575 \\
\hline$\Sigma_{\mathrm{n}}$ & 138.6 & 146.5 & 113.4 & 100.6 & 120.1 & 127.5 & 123.7 & 111.0 \\
\hline$\%$ Elevation & ------ & ------ & ------- & ------ & 21.31 & 21.83 & 9.10 & 10.34 \\
\hline \multicolumn{9}{|l|}{ Zinc } \\
\hline Min. & 90.3 & 92.2 & 93.1 & 94.8 & 95.2 & 97.8 & 99.5 & 95.3 \\
\hline Max. & 130.3 & 142.7 & 134.3 & 134.6 & 140.1 & 143.7 & 147.3 & 141.4 \\
\hline Median & 110.4 & 137.7 & 122.7 & 120.5 & 121.6 & 130.7 & 139.6 & 134.3 \\
\hline Mean & 109.18 & 118.49 & 118.52 & 119.1 & 120.00 & 126.18 & 130.34 & 126.4 \\
\hline$\sigma_{n-1}$ & 15.656 & 22.62 & 16.926 & 16.28 & 19.509 & 19.494 & 20.76 & 19.29 \\
\hline$\Sigma_{\mathrm{n}}$ & 764.3 & 829.4 & 592.6 & 595.5 & 600.00 & 630.9 & 651.7 & 630.7 \\
\hline$\%$ Elevation & ------ & ------- & ------ & ------- & 9.91 & 6.50 & 9.97 & 6.13 \\
\hline
\end{tabular}

$\Sigma \mathrm{n}=$ sum of the total values and $\sigma_{\mathrm{n}-1}=$ sample standard deviation

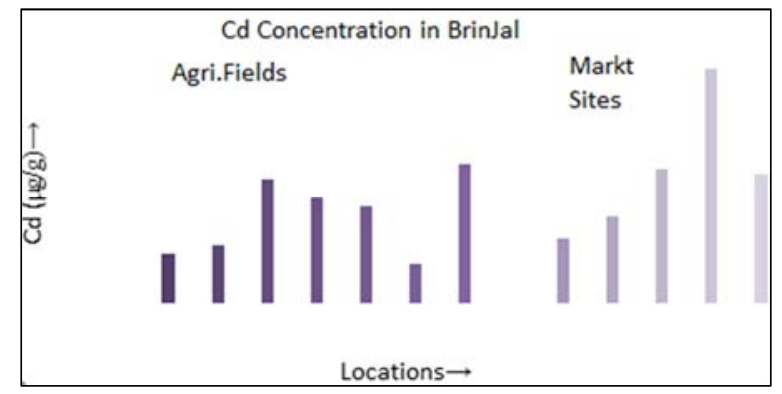

Figure 3. Concentration of $\mathrm{Cd}$ in brinjal.

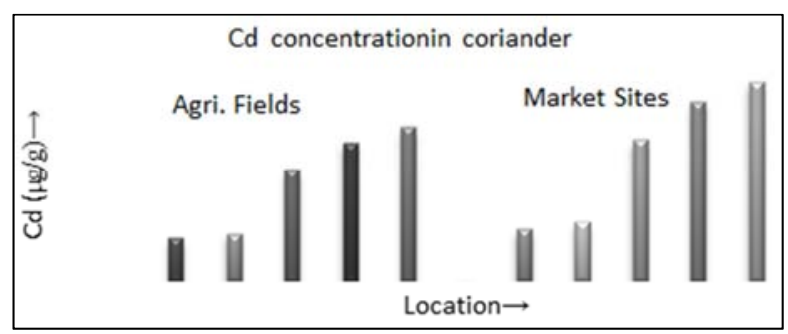

Figure 4. Concentration of $\mathrm{Cd}$ in coriander.

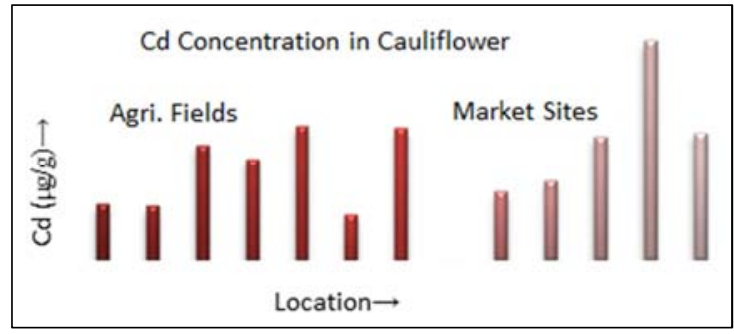

Figure 5. Concentration of $C d$ in cauliflower.

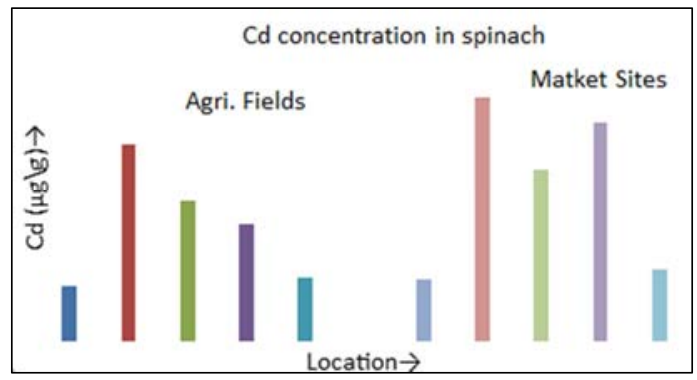

Figure 6. Concentration of $\mathrm{Cd}$ in spinach. 


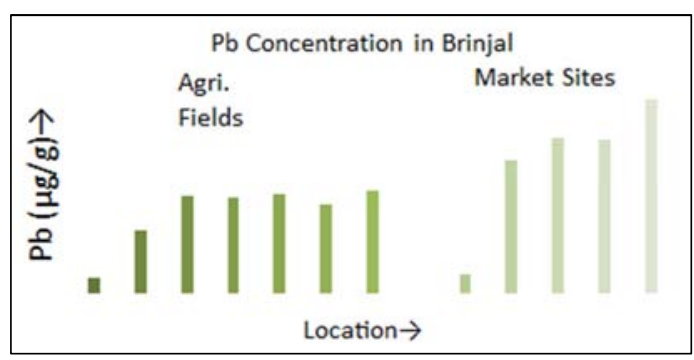

Figure 7. Concentration of $\mathrm{Pb}$ in brinjal.

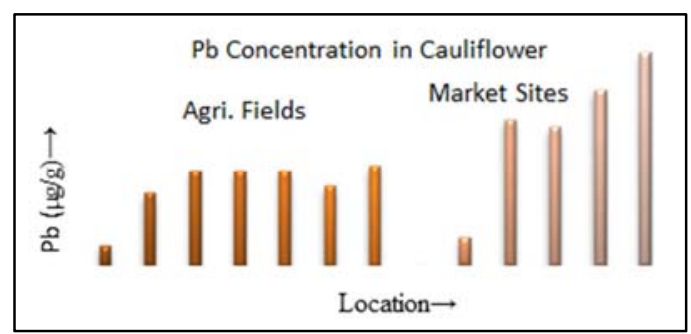

Figure 8. Concentration of $\mathrm{Pb}$ in cauliflower.

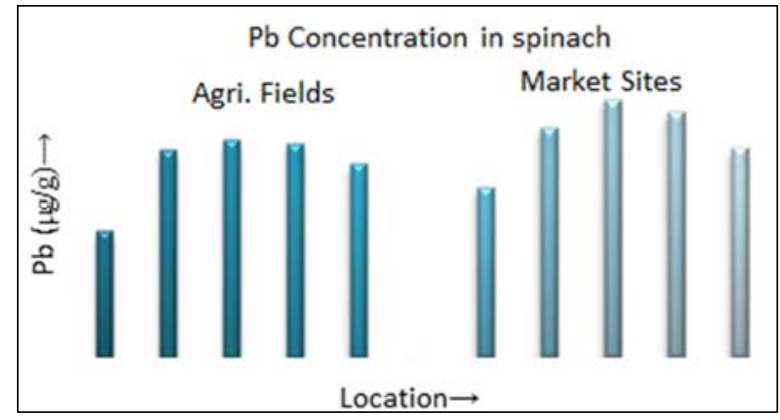

Figure 9. Concentration of $\mathrm{Pb}$ in spinach.

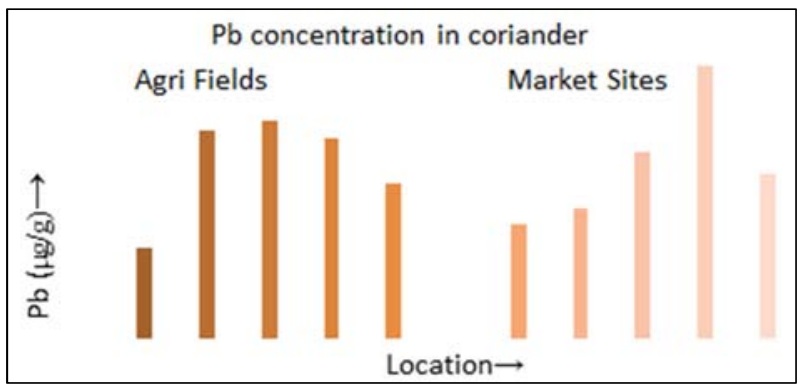

Figure 10. Concentration of $\mathrm{Pb}$ coriander.

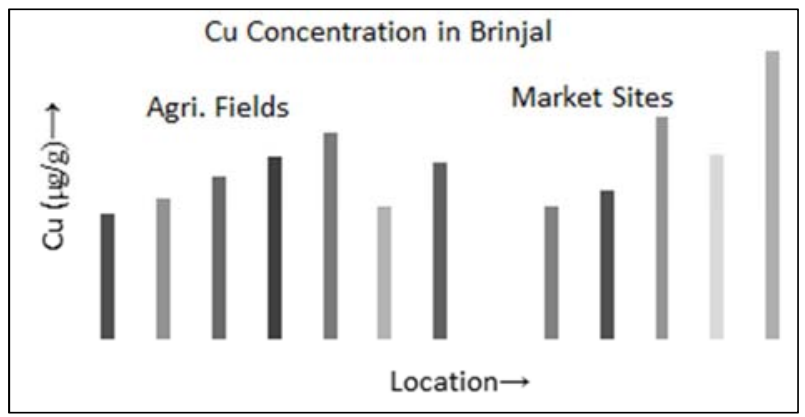

Figure 11. Concentration of $\mathrm{Cu}$ in brinjal.

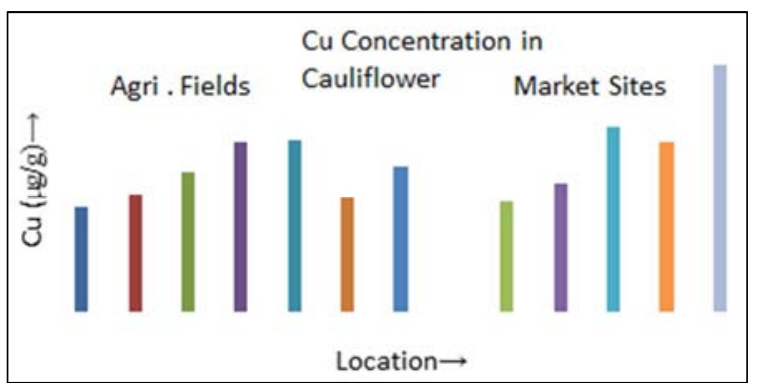

Figure 12. Concentration of $\mathrm{Cu}$ in cauliflower.

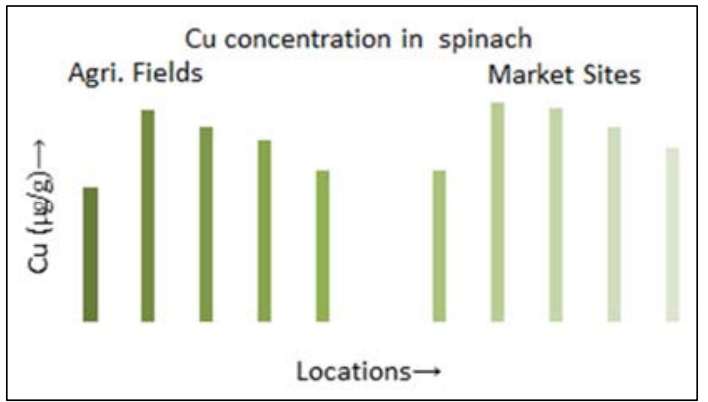

Figure 13. Concentration of $\mathrm{Cu}$ in spinach.

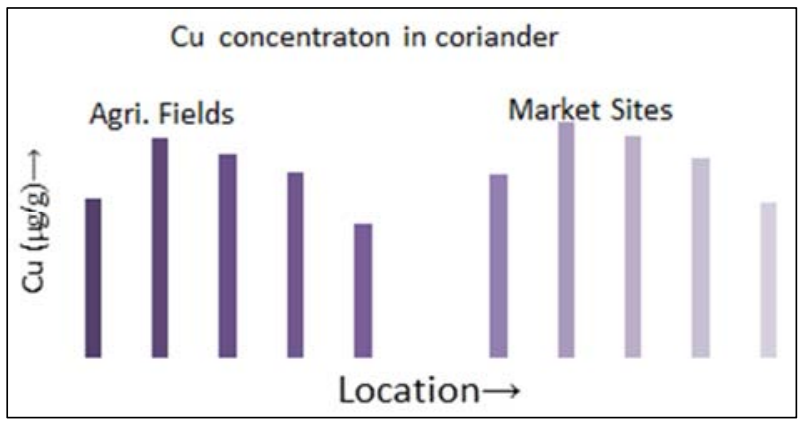

Figure 14. Concentration of $\mathrm{Cu}$ in coriander.

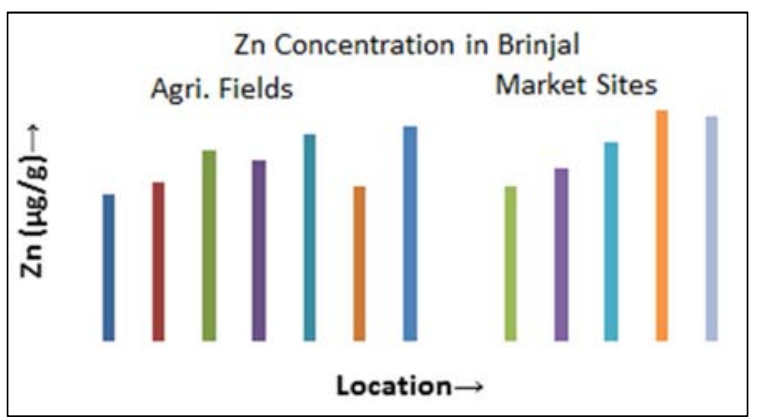

Figure 15. Concentration of $Z n$ in brinjal.

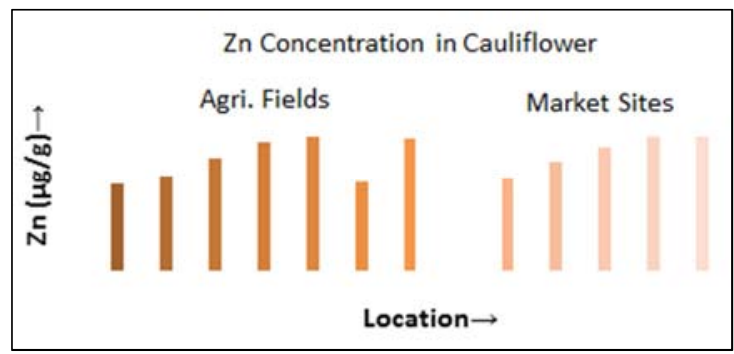

Figure 16. Concentration of $\mathrm{Zn}$ in cauliflower. 


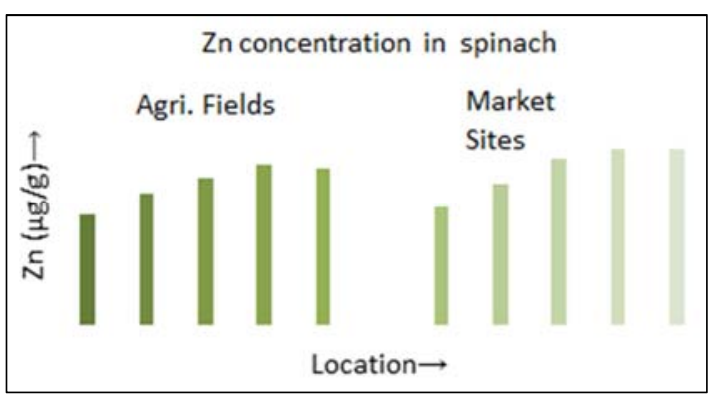

Figure 17. Concentration of $Z n$ in spinach.

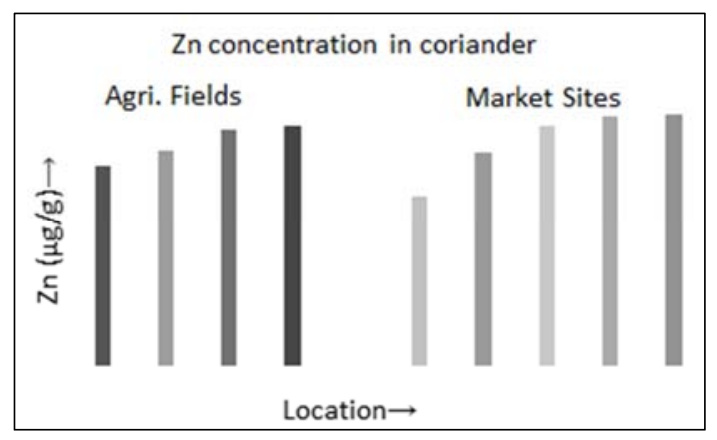

Figure 18. Concentration of $\mathrm{Zn}$ in coriander.

The maximum concentrations of $\mathrm{Cd}(\mu \mathrm{g} / \mathrm{g})$ in vegetable collected from market sites were recorded in spinach at siteII (3.84), at site-III (2.71), at site-IV (3.45), in coriander at site- III (2.71), at site-IV (3.45), at site-V (3.81), in brinjal at site-IV (2.1) and in cauliflower at sites-IV (2.2) as shown in Figures 3-6, which were higher than permissible limits of PFA $(1.5 \mu \mathrm{g} / \mathrm{g})$. The maximum accumulation of $\mathrm{Pb}(\mu \mathrm{g} / \mathrm{g})$ in vegetables collected from market at site- $\mathrm{V}$ in brinjal (2.54) and in cauliflower (2.84), at III in spinach (1.75) and at siteIV in coriander (2.43) as shown in Figures 7-10. $\mathrm{Pb}$ concentration in cauliflower and brinjal were slightly high and spinach and coriander were slightly lower than PFA standard $(2.5 \mu \mathrm{g} / \mathrm{g})$. Based on the results of the mean concentration of all metals, $\mathrm{Zn}$ showed high and $\mathrm{Pb}$ low levels in all the vegetables collected from agricultural and market sites. Similar results reported by various researchers, Sharma and Chettri (2005) [32], Sharma et al. (2009) [8] and Degheim et al. (2004) [33]. The absorption of heavy metals from the soil depends on different factors such as $\mathrm{pH}$, organic matter, soil metal availability, cation exchange capacity, plant species, plant growth stages and season and presence of other heavy metals in soil [34]. Data as shown in Table 4 the accumulation of $\mathrm{Cd}, \mathrm{Pb}, \mathrm{Cu}$ and $\mathrm{Zn}$ in the test vegetables collected from market sites and agricultural fields were compared and found that the levels of $\mathrm{Cd}, \mathrm{Pb}, \mathrm{Cu}$ and $\mathrm{Zn}$ increased by $47.83,64.84,21.3$ and $9.91 \%$ in brinjal, 36.19 , $78.09,21.83$ and $6.50 \%$ in cauliflower, $34.52,49.50,9.1$ and $9.97 \%$ in spinach and $27.68,47.05,10.34$, and $6.13 \%$ in coriander. The percent increase in the concentration of heavy metals was observed maximum in brinjal (143.88\%) followed by cauliflower (142.61\%), spinach $(103.09 \%)$, and coriander $(91.38 \%)$. The high accumulation of $\mathrm{Pb}$ and $\mathrm{Cu}$ were observed in cauliflower than other test vegetables may be due to it having a higher exposed area of inflorescence and hence greater capacity to absorb metals from atmosphere. The high accumulation of heavy metals in vegetables obtained from market sites may also be due to transportation and marketing processing of vegetables which may pose a threat to the quality of the vegetables with consequences for the health of consumers of locally produced foodstuffs, [35].

\subsection{Transfer Factor (TF)}

The transfer factor of $\mathrm{Cd}, \mathrm{Pb}, \mathrm{Cu}$ and $\mathrm{Zn}$ varied from $0.770-1.568,0.956-1.429,1.158-1.358,1.038-1.132$ and $0.965-2.367,1.576-1.717,1.329-1.526,1.141-1.239$ for vegetable collected from production and market sites respectively (Table 5). The TF of different heavy metals shows the following order- $\mathrm{TF}_{\mathrm{Cu}}>\mathrm{TF}_{\mathrm{Pb}}>\mathrm{TF}_{\mathrm{Zn}}>\mathrm{TF}_{\mathrm{Cd}}$ and $\mathrm{TF}_{\mathrm{Cd}}>\mathrm{TF}_{\mathrm{Pb}}>\mathrm{TF}_{\mathrm{Cu}}>\mathrm{TF}_{\mathrm{Zn}}>$ in case of vegetables collected from production and market sties respectively. To investigate the human health risk index metal transfer factor from soil to plant is essential tool (Cui et al., 2004). The high uptake of metals in these vegetables may be reason to high transpiration rate to sustain the growth and moisture content in leafy vegetables [36]. The transfer factor for $\mathrm{Cd}, \mathrm{Pb}, \mathrm{Cu}$ and $\mathrm{Zn}$ greater than one in most test vegetables indicates, greater accumulation and these metals have high transfer factor that migrate to the edible part of the vegetables [37].

Table 5. TF of heavy metals from soil to vegetables collected from production and market sites.

\begin{tabular}{|c|c|c|c|c|c|c|c|c|c|c|}
\hline \multicolumn{6}{|c|}{ Agricultural (production) Fields } & \multicolumn{5}{|c|}{ Market Sites } \\
\hline Vegetables & Cd & $\mathbf{P b}$ & $\mathbf{C u}$ & $\mathbf{Z n}$ & $\Sigma_{\mathrm{TF}}$ & Cd & $\mathbf{P b}$ & $\mathbf{C u}$ & $\mathbf{Z n}$ & $\Sigma_{\mathrm{TF}}$ \\
\hline Brinjal & 0.770 & 0.956 & 1.158 & 1.038 & 3.922 & 0.965 & 1.576 & 1.438 & 1.141 & 5.12 \\
\hline Cauliflower & 0.888 & 1.143 & 1.253 & 1.126 & 4.41 & 1.209 & 1.717 & 1.526 & 1.199 & 5.651 \\
\hline Spinach & 1.057 & 1.190 & 1.358 & 1.127 & 4.732 & 2.367 & 1.386 & 1.481 & 1.239 & 6.473 \\
\hline Coriander & 1.568 & 1.429 & 1.204 & 1.132 & 5.333 & 2.357 & 1.418 & 1.329 & 1.199 & 6.303 \\
\hline$\Sigma_{\mathrm{TF}}$ & 4.283 & 4.718 & 4.973 & 4.423 & 8.397 & 6.898 & 6.097 & 5.774 & 4.778 & 25.547 \\
\hline
\end{tabular}

The soil-plant transfer factor of heavy metals in vegetable collected from market sites was found to be higher than vegetable collected from production sites. High TF $(>1)$ for metals in vegetables collected from production sites was due to the vicinity of brick kilns or near to national highway, whereas high TF $(>1)$ for metals in vegetables collected from market sites was due to heavy metals deposition on the vegetables during transport and marking in more polluted urban environment of Katihar city. High TF values were observed for $\mathrm{Cd}, \mathrm{Pb}, \mathrm{Cu}$ and $\mathrm{Zn}$ metals with test vegetables 
and could be one of the possible reasons for health risk in human via their consumption

\subsection{Daily Intake of Metals (DIM)}

The DIM ( $\mu \mathrm{g}$ day $\left.^{-1}\right)$ values through consumption of test vegetables are given in Table 6 . The results revealed that daily intakes of $\mathrm{Cd}, \mathrm{Pb}, \mathrm{Cu}$ and $\mathrm{Zn}$, by adults in vegetables collected from agricultural fields and market sites were found to be
2.078, 1.908, 33.27, $179.60 \mu \mathrm{g} /$ day and 3.228, 2.563, 38.198, $202.03 \mu \mathrm{g} /$ day respectively. The DIM was in order of: DIM $\mathrm{Zn}>\mathrm{DIM}_{\mathrm{Cu}}>\mathrm{DIM}_{\mathrm{Cd}}>\mathrm{DIM}_{\mathrm{Pb}}$ for vegetables collected from both production and markets sites. The daily intake of heavy metals through consumption of test vegetables collected from market sites was found to be higher compare the vegetables collected from agricultural fields.

Table 6. Daily intake of metals ( $\mu \mathrm{g}$ day-1) in vegetables collected from production and market sites.

\begin{tabular}{lllllllllll}
\hline \multicolumn{1}{l}{ Agricultural (production) Fields } & \multicolumn{9}{c}{ Market Sites } \\
\hline Vegetables & $\mathbf{C d}$ & $\mathbf{P b}$ & $\mathbf{C u}$ & $\mathbf{Z n}$ & $\boldsymbol{\Sigma}_{\text {TF }}$ & $\mathbf{C d}$ & $\mathbf{P b}$ & $\mathbf{C u}$ & $\mathbf{Z n}$ & $\boldsymbol{\Sigma}_{\text {TF }}$ \\
\hline Brinjal & 0.303 & 0.402 & 7.643 & 42.145 & 50.493 & 0.448 & 0.662 & 9.272 & 46.32 & 56.702 \\
Cauliflower & 0.351 & 0.405 & 8.078 & 45.735 & 54.569 & 0.912 & 0.722 & 9.843 & 48.71 & 60.187 \\
Spinach & 0.695 & 0.500 & 8.754 & 45.748 & 55.695 & 0.936 & 0.583 & 9.549 & 58.31 & 69.378 \\
Coriander & 0.729 & 0.601 & 8.801 & 45.973 & 56.109 & 0.932 & 0.596 & 9.534 & 48.69 & 59.752 \\
$\Sigma_{\text {DIM }}$ & 2.078 & 1.908 & 33.27 & 179.60 & 216.86 & 3.228 & 2.563 & 38.198 & 202.03 & 246.02 \\
\% of PDTI & 3.463 & 0.892 & 1.109 & 0.0029 & ------ & 5.380 & 1.197 & 4.606 & 0.336 & ----- \\
\hline
\end{tabular}

PTDI Cd $=60 \mu \mathrm{g}_{\text {day }}{ }^{-1}, \mathrm{~Pb}=214 \mu \mathrm{g} \mathrm{day}^{-1}, \mathrm{Zn}=60 \mathrm{mg} \mathrm{day}^{-1}$ and $\mathrm{Cu}=3 \mathrm{mg} \mathrm{day}^{-1}$

The results show agreement with previous studies showing levels of heavy metals in edible part of food crops irrigated continuously with wastewater $[38,39]$, the results also showed that the present findings were lower than 54 $\mu \mathrm{g} /$ day and $412 \mu \mathrm{g}$ /day of $\mathrm{Pb}$ in adult as reported by Debeca et al. (1987) [40] and Dick et al. (1987) [41] respectively and also lower than 21.6, 858.6, 426.6 and 3.7 $\mathrm{mg}$ /day for $\mathrm{Cd}, \mathrm{Cu}, \mathrm{Pb}$ and $\mathrm{Zn}$ respectively as reported by Bahemuka and Mubofu (1999) [42]. The data also revealed that consumption of vegetables collected from market to daily intake of $\mathrm{Cd}, \mathrm{Pb}, \mathrm{Cu}$ and $\mathrm{Pb}$ were of 5.38, 1.2, 4.606 and $0.336 \%$ of provisional tolerable daily intake (PTDI) respectively. Thus the consumption of average amount of these contaminated vegetables does not pose health risk for consumers [43].

\subsection{Health Risk Index (HRI)}

The HRI values for consumers showed in the following order $\mathrm{Cd}(3.228)>\mathrm{Cu}(0.955)>\mathrm{Zn}(0.672)>\mathrm{Pb}(0.640)$ and $\mathrm{Cd}$ $(2.078)>\mathrm{Cu}(0.831)>\mathrm{Zn}(0.597)>\mathrm{Pb}(0.477)$ through consumption of test vegetables collected from market sites and agricultural fields respectively (Table 7). The results revealed that HRI value for all individual vegetable collected from market sites was higher compare to vegetable collected from production sites but found to be less than 1.0. The results of the study are in agreement with those reported by Khan et al. (2010) [44], Jan et al. [26] and lower than those reported by Gupta et al. [45] $(\Sigma=6.25)$. The HRI less than 1 for $\mathrm{Cd}, \mathrm{Pb}, \mathrm{Zn}$, and $\mathrm{Cu}$ through consumption of all test vegetables of the studied area suggest that all vegetables collected from agricultural lands and from market sites were almost safe for consumer.

Table 7. HRI for heavy metals in vegetables collected from production and market sites.

\begin{tabular}{|c|c|c|c|c|c|c|c|c|c|c|}
\hline \multicolumn{6}{|c|}{ Agricultural (production) Fields } & \multicolumn{5}{|c|}{ Market Sites } \\
\hline Vegetables & $\mathrm{Cd}$ & $\mathbf{P b}$ & $\mathrm{Cu}$ & $\mathbf{Z n}$ & $\Sigma_{\text {HRI }}$ & Cd & $\mathbf{P b}$ & $\mathrm{Cu}$ & $\mathrm{Zn}$ & $\Sigma_{\text {HRI }}$ \\
\hline Brinjal & 0.303 & 0.101 & 0.191 & 0.140 & 0.735 & 0.448 & 0.165 & 0.232 & 0.154 & 0.999 \\
\hline Cauliflower & 0.351 & 0.101 & 0.202 & 0.152 & 0.806 & 0.912 & 0.180 & 0.246 & 0.162 & 1.500 \\
\hline Spinach & 0.695 & 0.125 & 0.218 & 0.152 & 1.190 & 0.936 & 0.146 & 0.239 & 0.194 & 1.515 \\
\hline Coriander & 0.729 & 0.150 & 0.220 & 0.153 & 1.252 & 0.932 & 0.149 & 0.238 & 0.162 & 1.481 \\
\hline$\Sigma_{\text {HRI }}$ & 2.078 & 0.477 & 0.831 & 0.597 & 3.983 & 3.228 & 0.640 & 0.955 & 0.672 & 5.495 \\
\hline
\end{tabular}

\section{Conclusion}

The present study showed that levels of heavy metals in all test vegetables collected from market sites were higher than those collected from agricultural fields. In both sites mean concentration of $\mathrm{Cu}, \mathrm{Zn}, \mathrm{Cd}$ and $\mathrm{Pb}$ were lower than PFA standards. The TF, DIM and HRT values for heavy metals in all test vegetables collected from market sites were also found to be higher than those collected from agricultural fields. The results also indicated the variation of accumulation of heavy metals in vegetables tested may be due to anthropogenic activities like continuous irrigation with sewage and wastewater, addition of agro chemicals, use of metal-based pesticides, traffic load, brick kiln industries around production sites and polluted urban environment of Katihar city. Dietary intake of food results in long-term low level body accumulation of heavy metals and the detrimental impart become visible only after long time exposure. 
The present research work further suggested that the regular monitor of heavy metals in vegetables is essential to reduce the health risk. Vegetables should be washed properly to remove aerial contamination from surface of vegetables and appropriate precaution should be taken at the time of marketing of vegetables.

\section{References}

[1] Shuaibu, I. K., Yahaya, M., Abdullahi, U. K., 2013. Heavy metal levels in selected green leafy vegetables obtained from Katsina central market, Katsna, North-western Nigeria. African Journal of Pure and Applied Chemistry, 7(5): 179183, DOI: 10.5897/AJPAC 2013.0499.

[2] Ramteke, S., Bharat, B. L., Dahariya, N. S., Patel, K. S., 2016. Heavy metal contamination of vegetables. Journal of Environmental Protection, 7: 996-1004, http;//dx.doi.org/10.4236/jep.2016.77088.

[3] Aktauzzaman, M., Fukhruddin, A. N. M., Chowdhry, M. A. A., Fardous, Z., Alum, M. K., 2013. Accumulation of Heavy Metals in Soil and their Transfer to Leafy Vegetables in the Region of Dhaka Aricha Highway, Savar, Bangladesd. Pakistan Journal of Biological Science, 16(7): 332-338, DOI: 10.3923/pjbs.2013.332.338.

[4] Hamid, A., Raza, H., Akhtar, S., Ahmad, S. R., 2016. Heavy Metal Contamination in Vegetables, Soil and Water and Potential Health Risk Assessment. American- Eurasian J. Agric. \& Environ. Sci., 16 (4): 786-786, DOI: 10.5897/idosiaejaes.2016.16.04. 103149.

[5] Mahmood, A. Malik, R. N., 2014. Human health risk assessment of heavy metals via consumption of contaminated vegetables collected from different irrigation sources in Lahore, Pakistan. Arabian Journal of Chemistry, 7: 91-99.

[6] Rasheed, H., Jaleel, F., Nisar, M. F., 2014. Analyzing the Status of Heavy Metals in Water in Suburban Areas of Bahawalpur City, Pakistan. American-Eurasian J. Agric. \& Environ. Sci., 14 (8): 732-738, DOI: 10.5897/idosi-aejaes. 2014.14.08. 12380.

[7] Al Jassir, M. S., Shaker, A., Khaliq, M. A., 2005. Deposition of heavy metals on green vegetables sold on roadsides of Riyadh city, Saudi-Arabia. Bull. Environ. Contaminant Toxicology, 75: 1020-1027.

[8] Sharma, R. K., Agrawala, M. and Marshal, F. M., 2009. Heavy metal in vegetables collected from production and market sites of tropical urban of India. Food and Chemical Toxicology, 47: 583-591, doi: 10.1016/j.fct.2008.12.016.

[9] Sharma, R. K., Agrawala, M. and Marshal, F. M., 2008a. Heavy metals $(\mathrm{Cu}, \mathrm{Cd}, \mathrm{Zn}$ and $\mathrm{Pb})$ contamination of vegetables in urban India: a case study in Varanasi. Environ. Poll. 154: 254-263.

[10] Sharma, R. K., Agrawala, M. and Marshal, F. M., 2008b. Atmospheric deposition of heavy metals $(\mathrm{Cd}, \mathrm{Zn} \mathrm{Pb}$ and $\mathrm{Cu}$, $)$ in Varanasi city, India.. Environ. Monit. Assess. 142 (-3): 269-278.

[11] Kumar, A., Seema, 2016. Accumulation of heavy Metals in Soil and Green Leafy Vegetables Irrigated with Wastewater. IOSR- J. Environ. Sci. Toxicol. Food Technol., 10(7): 8-19.

[12] Balkhair, K. S. and Ashraf, M. A., 2015. Field accumulation risks of heavy metals in soil and vegetable crop irrigated with sewage water in western region of Saudi Arabia. Saudi Journal of Biological Sciences, 23: S32-S44. http;//dx.doi.org/10.1016/j-sjbs.2015.09.023.

[13] Pirsaheb, M., Khosravi, T., Sharafi, K.., Babajani, L., Rezaei, M., 2013. Measurement of heavy metals concentration in drinking water from source to consumption sites in Kermanshah-Iran. World App. Sci. J., 21 (3): 416-423.

[14] Momodu, M. A., Anyakora, C. A., 2010. Heavy metals concentration of ground water: The Surulere case study Res. J. Environmental and Earth Sci., 2 (1): 39-43.

[15] Kumar, A., Kumar, V., 2015. Seasonal variation of toxic metals in groundwater resources of Kishanganj district, Bihar, India J. Chem. Pharm. Res., 7(4): 187-198.

[16] Jena, V., Dixit, S., Gupta, S., 2012. Risk assessment of heavy metal toxicity through edible vegetables from industrial area of Chhattisgardh. Int. J. Res. Environ. Sci. Technol., 2 (4): 124-127.

[17] Yuan, Li-zhu, Bo Song, Yu-fei Huang, Feng-yan Fu, Lu. Sufen Lu and Xue-mei Zhong, 2015. Health Risk of Heavy Metals to the General Inhabitants in Guilin, China via Consumption of Vegetables. In the Proceeding of the AASRI International Conference on Industrial Electronics and Applications (IPA 2015), UK, June 27-28 and pp: 445-457.

[18] Khan, S., Farooq, R., Shahabaz, S., Khan, M. A., Sadique, M., 2009. Health Risk Assessment of Heavy Metals for Population via Consumption of vegetables. World Applied Science Journal 6 (12): 1602-1606.

[19] Lei, M., Liao, B., Zeng, Q., Quin, P., Khan, S., 2008. Fraction distribution of lead, cadmium, copper and zinc in metal contaminated soil before and after extraction and disodiumethylenediaminetetraacetic acid. Common Soil, Sci. Plant Anal., 38: 1963-1978.

[20] Jamali, M. K., Kazi, T. G., Arain, A. M., Afridi, H. I., Jalbani, N., Kandhro, G. A., Saha, A. Q., Baig, J. A., 2009. Heavy metals accumulation in different varieties of wheat (Triticum aestivum L.) grown in soil amended with domestic sewage sludge. J. Hazard. Mater, 164: 1336-1391.

[21] Allen, S. E., Grimshaw, H. M., Rowland, A. P., 1986. Chemical analysis. In: Methods in Plant Ecology Eds. Moore, P. D., Chapman, S. B. (Eds.). Methods in Plant Ecology, Oxford: Blackwell Scientific Publication, London, pp: 285-344.

[22] Liu, W. H., Zhao, J. Z., Ouyang, Z. Y., Soderlund, I. Liu, G. H., 2005. Impacts of sewage irrigation on heavy metals distribution and contamination in Beijing, China. Environment International 31: 805-812.

[23] Cui, Y. J., Zhu, Y. G., Zhai, R. H., Chen, D. Y., Huang, Y. Z., Qiu, Y. and Liang, J. Z,. 2004. Transfer of metals from soil to vegetables in an area near a smelter in Nanning, China. Environ. Int. 30 (6): 785-791.

[24] Chary, N. S., Kamala, C. T., Raj, D. S. S., 2008. Assessing risk of heavy metals from consuming food grown on sewage irrigated soils and food chain transfer. Ecotoxicol Environ, Safety, 69: 513-524.

[25] Rattan, R. K., Datta, S. P., Chhonkar, P. K., Suribabu, K.., Singh, A. K., 2005. Long term impact of irrigation with sewage effluents on heavy metal content in soils, crops and groundwater - a case study. Agriculture, Ecosystem and Environment 109: 310-322. 
[26] Jan, F. A., Ishaq, M., Khan, S., Ihsanullah, I., Ahmad, I., Shakirullah, M., 2010. A comparative study of human health risks via consumption of food crops grown on wastewater irrigated soil (Peshawar) and relatively clean water irrigated soil (lower Dir). J. Hazard. Mater, 179: 612-621.

[27] US-EPA IRIS. 2006. United States, Environmental Protection Agency, Integrated Risk Information System. $<$ http://www.epa. gov/iris/substS>.

[28] Temmerman, L. O., Hoenig, M., Scokart, P. O., 1984. Determination of "normal" levels and upper limit values of trace elements in soils. Z. Pflanzenernähr. Bodenkd, 147: 687694.

[29] Awasthi, S. K., 2000. Prevention of food Adulteration Act No.37 of 1954. Central and State Rules as Amended for 1999, $3^{\text {rd }}$ ed. Ashoka Law House, New Delhi.

[30] Singh, K. P., Madan, D., Sinha, S., Dalwani, R., 2004. Impact assessment of treated/untreated wastewater toxicant discharge by sewage treatment plant on health, agricultural and environmental quality in wastewater disposal area. Chemosphere, 55: 227-255.

[31] Krishana, A. K., Govil, P. K., 2007. Soil contamination due to heavy metals from industrial area of Surat, Gujarat, Western, India. Environ. Monit. Asses, 124 (1-3): 263-275.

[32] Sharma B., Chettri, M. K.., 2005. Monitoring of heavy metals in vegetables and soil of agricultural field of Kathmandu Valley. Ecoprint, 12: 1- 9.

[33] Deghein, S. M., El-Asharif, M. M., Gad Alla, S. A., Khorshid, M. A., Falmuy, S. M., 2004. Pesticides and heavy metals levels Egyptian leafy vegetables and some aromatic medical plats. Food Additives and contaminated.21: 323-330.

[34] Sharma, R. K., Agarwal, M., Mashall, F. M., 2006. Heavy metals contamination in vegetables grown in wastewater irrigated area of Varanasi, India. Bull. Environ. Contam. Toxcol. 77 (2): 322-318.

[35] Shakya, P. R., Khwaounjoo, N. M., 2013. Heavy metal contamination in green leafy vegetables collected from different market sites of Kathmandu and their associated health risks. Scientific World, 11(11): 37-42.
[36] Tam, F. H., Barrington, S., 2005. Zinc and copper in take by plant under transportation ratio Part I. Wheat (Triticumaestivum L.). Environ. Pollut. 138: 538-547.

[37] Luo, C., Liu, C., Wang, Y., Liu, X., Li, F., Zhang, G., Li, X., 2011. Heavy metal contamination in soils and vegetables near an e-waste processing site, south china. J. Hazard. Mater, 186 (1): 481-490.

[38] Khan, S., Cao, Q., Zheng, Y. M., Huang, Y. Z., Zhu, Y. G., 2008. Health risks of heavy metals in contaminated soils and food crops irrigated with wastewater in Beijing, China. Environ. Poll. 152(3): 686-692.

[39] Liu, W. H., Zhao, J. Z., Ouyang, Z. Y., Sonderland, L., Liu, G. H., 2005. Impact of sewage irrigation on heavy metals distribution and contamination. Environment International, 31: 805-812.

[40] Debeca, R. W., Mckenzie, A. D., Lacroix, G. M. A., 1987. Dietary intakes of lead, cadmium, arsenic and fluoride by Canadian adults, $24 \mathrm{~h}$ duplicate diet study. Food Additives and Contaminants, 4: 89-10.

[41] Dick, G. L., Hughes, J. T., Mitchel, J. W., David, F., 1987. Survey of trace elements and pesticides in New Zealand. Journal of Science, 21: 57-69.

[42] Bahemuka, T. E., Mubofu, E. B., 1999. Heavy metals in edible green vegetables grown along the sites of the Sinza and Msimbazi rivers in Dares Salaam, Tanzania, Food Chemistry. 66: 63-66

[43] Joint FAO/WHO Expert Committee on Food Additives, 1999. Summary and conclusions, In the Proceeding of the $53^{\text {rd }}$ Meeting, Rome, and June 1-10.

[44] Khan, S. S., Rehman, A. Z., Khan, M. A., Shah, T., 2010. Soil and vegetables enrichment with heavy metals from geological sources in Gilgit, northern Pakistan. Ecotoxicol. Environ. Safety, 73: 1820-1827.

[45] Gupta, S., Jena, V., Jena, S., Davic, N., Matic, N., Rodajevic, D., Solanki, J. S., 2013. Assessment of heavy metal contents of green leafy vegetables. Croot. J. Food Sci. Technol., 5(2): 53-60. 